UDC 94(470)

Submitted: 31.08 .2020

LBC 63.3(2)64-3

Accepted: 22.01.2021

\title{
THE IDEA OF THE URAL REPUBLIC DURING THE STATE TRANSFORMATION OF THE RUSSIAN FEDERATION ${ }^{1}$
}

\author{
Igor V. Osipov \\ Moscow State University, Moscow, Russian Federation
}

\begin{abstract}
Introduction. The phenomenon of the Ural Republic in the context of the Russian Federation federal model of state structure formation in 1993 is studied. The process of the Russian federalism model development at this stage was complicated by a whole complex of problems and contradictions. The movement of the regional authorities in the Sverdlovsk region to create the Ural Republic in the context of the Russian post-Soviet model of the Federal structure is considered. Methods and materials. The archival materials of the Presidential Executive Office of Russia and state authorities of the Sverdlovsk region are the key sources of the research. The main group of materials for the article preparation consists of analytical notes reflecting the views of the current authorities on the nature of the state-territorial structure and fixing the expert and analytical view of the higher state authorities on the developing processes dynamics and the risks associated with them. Analysis. The process of the Ural Republic creation consisting of several stages is analyzed: forming an idea and holding a regional survey on equalizing the powers of the region with the republics; an attempt to offer its views on the federal structure at the Constitutional Assembly and to implement its achievements into the draft Constitution of the Russian Federation; the announcement of the Ural Republic creation by the leadership of the Sverdlovsk region, the establishment and protection of its position; abolition of the Ural Republic. Results. The Ural Republic phenomenon had some influence on the constitutional project development, but its elimination prevented not only the risks of so-called regional separatism, but also a potentially large state transformation, which consisted in the emergence of more independent regions, the formation of a new regional policy.

Key words: constitutional process, regional policy, the Russian Federation, the Ural Republic, federalism.

Citation. Osipov I.V. The Idea of the Ural Republic During the State Transformation of the Russian Federation. Vestnik Volgogradskogo gosudarstvennogo universiteta. Seriya 4. Istoriya. Regionovedenie. Mezhdunarodnye otnosheniya [Science Journal of Volgograd State University. History. Area Studies. International Relations], 2021, vol. 26, no. 3, pp. 217-226. (in Russian). DOI: https://doi.org/10.15688/jvolsu4.2021.3.19
\end{abstract}

\section{ИДЕЯ УРАЛЬСКОЙ РЕСПУБЛИКИ В ПЕРИОД ГОСУДАРСТВЕННОЙ ТРАНСФОРМАЦИИ РОССИЙСКОЙ ФЕДЕРАЦИИ ${ }^{1}$}

\author{
Игорь Вячеславович Осипов \\ Московский государственный университет им. М.В. Ломоносова, г. Москва, Российская Федерация
}

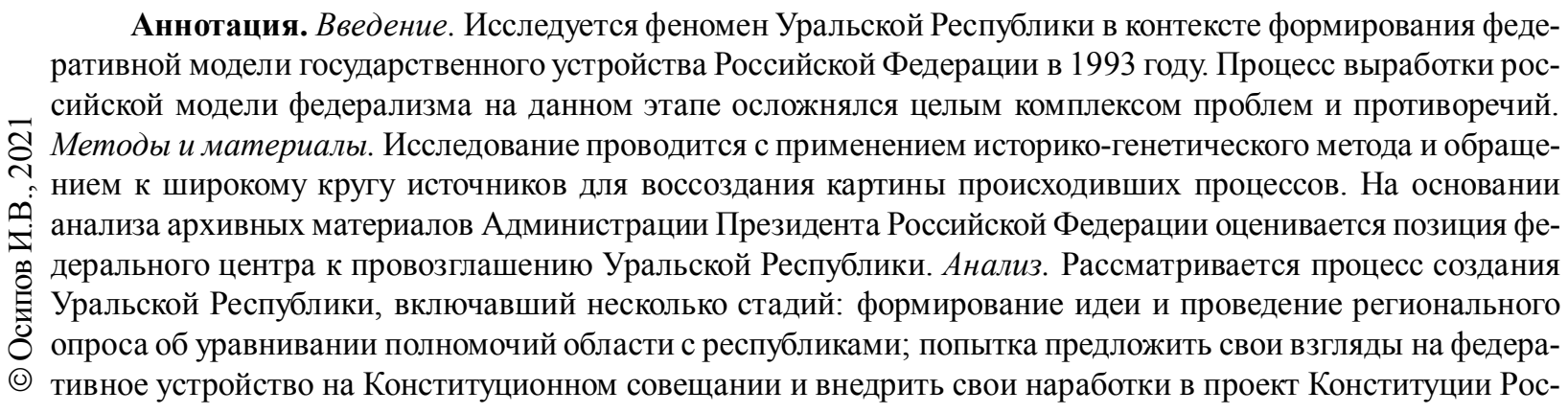




\section{ИНСТИТУЦИОНАЛИЗАЦИЯ РЕГИОНАЛЬНОГО ПРОСТРАНСТВА РФ}

сийской Федерации; объявление руководством Свердловской области о создании Уральской Республики, обоснование и защита своей позиции; принятие Конституции Уральской Республики и очередная попытка повлиять на заключительном этапе разработки проекта Конституции Российской Федерации на будущую модель федеративного устройства; упразднение Уральской Республики. Региональный фактор играл существенную роль в государственной и политической трансформации России, при этом оценки этого фактора со стороны представителей федеральных органов власти были отрицательными на протяжении всего процесса создания Уральской Республики. Результаты. В заключении автор исследования приходит к выводу о том, что, несмотря на признание всех решений по созданию Уральской Республики юридически недействительными, данный феномен оказал некоторое влияние на разработку конституционного проекта, однако ликвидация Уральской Республики в форме, выбранной Администрацией Президента Российской Федерации, пресекла не только риски так называемого провинциального сепаратизма, но и потенциально иную государственную трансформацию, заключавшуюся в появлении более самостоятельных субъектов, становлении новой региональной политики.

Ключевые слова: конституционный процесс, региональная политика, Российская Федерация, Уральская Республика, федерализм.

Цитирование. Осипов И. В. Идея Уральской Республики в период государственной трансформации Российской Федерации // Вестник Волгоградского государственного университета. Серия 4, История. Регионоведение. Международные отношения. - 2021. - Т. 26, № 3. - С. 217-226. - DOI: https://doi.org/10.15688/ jvolsu4.2021.3.19

Введение. После распада Советского Союза действующая власть РСФСР осталась наедине с проблемами, возникшими в самых разных сферах. Одним из системных вопросов прежнего периода, угрожающих государственной целостности, оставался вопрос федеративного устройства, при разрешении которого было необходимо выстраивать административно-территориальную модель, преодолевать асимметрию субъектов и осуществлять децентрализацию. Подписание Федеративного договора в 1992 г. не разрешило накопившиеся противоречия, поскольку, во-первых, субъекты оказались разделены на три категории с разным набором полномочий; во-вторых, в тяжелых социальноэкономических условиях крайне медленно осуществлялась разработка специального законодательства, регламентирующего разграничение предметов ведения и реализацию полномочий органов власти федерального и регионального уровней.

В этих условиях в Свердловской области зародилось движение по созданию Уральской Республики, одной из целей которого являлось изменение принципиальных основ федеративной модели и государственно-территориального устройства Российской Федерации. В 1993 г. шаги по повышению своего конституционноправового статуса сделали в ряде других областей (и даже в городе федерального значения Санкт-Петербург), но ни один из субъек- тов не продвинулся столь далеко по пути реализации своих намерений.

Вопросы федеративного устройства и региональной политики актуальны и на современном этапе. В этой связи представляется целесообразным обращение к событиям недавнего прошлого, имеющим ключевое значение в формировании государственных основ Российской Федерации.

Методы и материалы. Изучением данного периода занимаются представители различных научных дисциплин: политологи, конституционалисты, историки, социологи и др. Непосредственно процессу создания Уральской Республики посвящено небольшое количество научных работ $[9 ; 11 ; 12 ; 26 ; 28 ; 33]$. В рамках настоящего исследования проводится рассмотрение процесса развития инициативы властей Свердловской области по уравниванию конституционно-правового статуса с сопоставлением позиции Администрации Президента Российской Федерации по поводу данной тенденции в регионах России.

Исследование опирается на анализ широкого круга источников: аналитические материалы Администрации Президента Российской Федерации; материалы региональной и федеральной периодической печати, в которых публиковались позиции руководителей Свердловской области, взгляды политиков и государственных деятелей федерального уровня, официальные документы по повышению ста- 
туса области до республиканского уровня. Исследование проводится с применением историко-генетического метода и обращением к архивным материалам для воссоздания происходивших процессов.

Анализ. Ключевым направлением государственной трансформации в 1993 г. стала разработка проекта Конституции Российский Федерации, одним из узловых вопросов которой являлось государственно-территориальное устройство. Аналитики Государственно-правового управления Администрации Президента выделяли четыре модели, разработанные в ходе общественно-политических дискуссий. Исключительность положения состояла в том, что при выборе любого из вариантов требовалось соблюдение следующих условий:

- обеспечение равенства политических прав и объема полномочий русских и нерусских образований (кроме форм включения в федерацию и прав на национальный язык);

- перераспределение полномочий и законодательных прав от центра к регионам с обязательным приоритетом федерального законодательства в тех сферах, которые совместно регулировались федеральными и региональными властями;

- возможное создание национальных парламентов для народов, не имеющих своей государственности [4, л. 4-6].

Проблема федеративного устройства обострилась в связи с противоборством между Верховным Советом и Президентом Российской Федерации, которое отражалось на усилении национального и регионального сепаратизма. В Государственно-правовом управлении сепаратизм воспринимался как «опасный катализатор для разрушения российской государственности по образцу СССР, но в новой модификации. Роль союзных республик играют бывшие автономии, а этнических меньшинств - русские, которых подавляющее большинство» $[4$, л. 10].

В Центре оперативной информации Администрации Президента сделали попытку отыскать решение проблемы территориального устройства на материале российской истории. Однако отечественная история, по их мнению, не предоставляла «прецедентов разграничения полномочий центра и регионов»: «Даже самый беглый взгляд на российскую историю убеждает, что административно-государственное устройство страны всегда было выражено в крайне централизаторских тенденциях» [3, л. 36].

Не найдя положительных примеров разграничения полномочий в российской истории, аналитики Администрации Президента обратились к мировому опыту. Ими было выделено то, что в составе федеративных государств практически не бывает других суверенных государств; субъекты обладают большой самостоятельностью, но при этом они «озабочены не утверждением деклараций, призванных демонстрировать их “преимущество" перед остальным миром, а стремлением обеспечить целостность государства представлением каждому из субъектов Федерации полноты прав и возможностей, необходимых для самостоятельного решения вопросов собственного развития, согласуясь с общими интересами союзного государства в целом» [3, л. 37].

Авторы аналитической справки, подводя итог, отметили, что российские субъекты и сам центр «еще проходят путь, пройденный цивилизованным миром и демократией Запада. Научила ли их российская история и мировой опыт золотому правилу “не распылять власть только ради децентрализации и не концентрировать ее только ради централизации, а определять для нее тот уровень, на котором она будет наиболее действенной и полезной для управления?"» [3, л. 38].

Таким образом, в 1993 г. поиск модели федеративного устройства продолжался уже несколько лет, и оптимального варианта найдено не было. Вместе с тем активизировались регионы с инициативами по расширению своих прав и полномочий, получению большей самостоятельности. Внутри президентской команды такие предложения воспринимались как определенные угрозы для государственности.

В 1993 г. Свердловский областной Совет народных депутатов, тщетно пытаясь прежде заключить отдельное соглашение с федеральным центром по поводу механизма реализации совместной и исключительной компетенции, представил программу «нового федерализма», в рамках которой региональная политика «должна быть преимущественно 
собственной политикой регионов, а не политикой Центра по отношению к ним». Строительство федеративного государства было предложено вести на следующих принципиальных основах:

- четкое разделение компетенции федерации и ее субъектов, определение совместной компетенции и исключительной компетенции субъекта;

- равенство федерации и субъектов в федеративном процессе;

- равноправие федерации и ее субъектов по отношению к «наследству» унитарного государства с проведением передачи регионам прав, собственности и ресурсов договорным путем;

- приоритет субъектов в исполнении федеральных функций на своей территории над ведомствами федерального подчинения;

- достаточность полномочий субъектов для выбора и реализации своего особого пути в проведении общероссийских реформ [27, с. 7].

Не получив удовлетворительной реакции на свои инициативы, власти Свердловской области перешли к более решительным действиям. В день проведения Всероссийского референдума 25 апреля 1993 г. в Свердловской области был инициирован опрос жителей по следующему вопросу: «Согласны ли Вы с тем, что Свердловская область по своим полномочиям должна быть равноправна с республиками в составе Российской Федерации?» [24, л. 77].

В региональной прессе было проведено широкое освещение и объяснение важности голосования по дополнительному вопросу. Сообщалось, что область лишь формально является субъектом РФ, реальных возможностей улучшить свою жизнь не получила, подписав Федеративный договор. «Если права не дают, будем их отвоевывать», - заявлялось в публикации [23].

Итоги опроса были следующими: в голосовании приняли участие 2314993 чел. $(66,99 \%)$; среди них 83,36 \% граждан высказались за равные полномочия области с республиками [5]. Свердловские власти получили весомый аргумент для дальнейшей деятельности по развитию статуса области [20, л. $3 ; 21]$. На Конституционное совещание, которое было открыто 5 июня, делегация Свердловской области отправилась со своими предложениями по проекту Конституции, в том числе в отношении федеративного устройства [21].

Во время пленарного заседания Конституционного совещания глава администрации Свердловской области Э.Э. Россель напомнил об историческом опыте деления государства на губернии, а также отметил: «...Несомненно поддерживается всеми главами администраций... то, что должен быть единый принцип равенства губерний и республик: экономического, правового и политического. Здесь абсолютно 100 \% глав администраций, все руководители поддерживают этот вопрос» [18].

Конечно, никакой стопроцентной поддержки у такого положения не было, поскольку руководители республик выступали против. Спустя несколько дней свердловские власти выступили с резкой оценкой хода Конституционного совещания. Позже председатель Свердловского областного Совета народных депутатов А.В. Гребенкин заявил о том, что приведенные доводы в пользу территориального деления федерации на Конституционном совещании не были услышаны: «Представители республик выступили категорически против такой постановки вопроса, а разработчики новой Конституции, увы, пошли у них на поводу». По его же признанию, именно «тупиковая ситуация на Конституционном совещании» по вопросу федеративного устройства «приблизила развязку - была провозглашена Уральская Республика» [32].

1 июля Свердловский областной Совет народных депутатов объявил Свердловскую область «республикой в составе Российской Федерации (Уральская Республика)» [25, л. 83]. Создание Уральской Республики, согласно принятой Декларации, преследовало цель укрепления целостности Российской Федерации и служило «усилению общероссийской государственности на основе реализации принципов федерализма, приемлемых для всех субъектов Российской Федерации». Основными субъектами Федерации «должны были стать республики в составе Российской Федерации» [6, л. 84-85].

Власти Свердловской области предприняли ряд мер для оформления нового конституционно-правового статуса субъекта [17, л. 93-97]. 
Одним из ключевых направлений деятельности стала работа по формированию общественного мнения, донесению своей позиции до сторонников идеи Уральской Республики. С этой целью были подготовлены информационно-аналитические материалы, а руководство области регулярно выступало публично.

В одном из таких материалов были изложены политические, экономические, правовые, исторические и природно-географические основания повышения статуса области [8, c. 121-124]. В число политических оснований были включены следующие: проблема территориально-государственного устройства, порождающая неравноправие граждан; обострение национального вопроса и угроза целостности единому государству; противоречивость новой российской государственности и старой формы отношений центра и регионов.

Схожая аргументация была представлена в другом материале, автор которого заявлял о необходимости отказа от национального компонента в государственном устройстве, поскольку «искусственная федерализация, в основу которой положен этнический фактор, означает дезинтеграцию и расчленение России как органического единства ее народов» $[1$, л. 2]. В качестве варианта решения проблемы государственно-территориального устройства предлагалось использовать территориальный принцип с историческим делением на губернии [1, л. 8-9; 15].

Позиции, сформулированные в справочных материалах, публично отстаивались региональными властями. Директор департамента главы администрации Свердловской области А.П. Воробьев в интервью местной газете назвал решение областного Совета народным актом, направленным «против "суверенизации” регионов России и против еегосударственного устройства по национальному признаку». По мнению Воробьева, не существует федераций с неравноправными субъектами, поэтому решение о создании Уральской Республики открыло путь к выравниванию статуса краев и областей по отношению к республикам и создало условия для устойчивой федерации, основанной на равенстве ее субъектов [22].

Глава администрации Свердловской области Э.Э. Россель подчеркивал, что Ураль- ская Республика не затрагивает государственный суверенитет, верховенство российских законов является обязательным для региона: «Речь идет об экономической, законотворческой и политической самостоятельности» [32]. Россель описывал структуру взаимоотношений между субъектом и федеральным центром следующим образом: «Центр устанавливает нам определенный заказ. Можно его назвать государственным. Его мы обязательно выполняем. Все, что сделано сверх госзаказа, остается на территории. То же самое и с отчислением налогов. Мы будем участвовать в финансировании всех общероссийских программ... Бесспорно, станем оказывать финансовую помощь и тем областям или республикам России, которые будут пока еще нуждаться в дотациях. Но помощь эта будет оказываться на договорной основе. Дотационная область или республика сама определит размеры и сроки нашего финансирования, а также предложит варианты расчета с нами» [32].

После провозглашения Уральской Республики в Государственно-правовом управлении Администрации Президента был подготовлен аналитический материал, посвященный анализу произошедшего и проявлению схожих тенденций в других субъектах Федерации. В материале было отмечено, что смысл подобных событий заключался не только в переименовании, но в принципиальном изменении формулы взаимоотношений с центром. Аналитики предположили дальнейшую трансформацию государственного устройства через получение субъектами собственной конституции, законодательного органа, правительства и судебной власти. При реализации такого варианта прогнозировалось то, что уже федеральному центру будут переданы только те полномочия, которые сами субъекты «посчитают необходимыми для сохранения единого государства» [2, л. 2]. Данная перспектива была оценена как «непосредственная угроза центральной власти, которая в перспективе (если регионы получат желаемые полномочия) не только может оказаться лишенной своего прежнего положения, но и, видимо, будет заменена координирующими органами, то есть сформирована снизу» [2, л. 9].

Отметим, что на протяжении 1993 г. со стороны Президента не предлагалось конкрет- 
ного варианта решения проблемы государственно-территориального устройства и фактически была выбрана тактика политического «лавирования» в целях получения поддержки со стороны регионов в конфликте с Верховным Советом. Президентской стороне было необходимо не обострять ситуацию с национальными республиками, сохраняя положения о суверенитете республик и текст Федеративного Договора в проекте Конституции, а также не предпринимать решительных мер в отношении деятельности областей и краев по повышению своих статусов.

Такая тактика сохранялась до силового разрешения конфликта с Верховным Советом. После этого, оставшись фактически единственным и полновластным федеральным актором, президентская сторона приступила к решительному разрешению вопросов по федеративному устройству.

В попытке предупредить действия федерального центра в спешном порядке была завершена работа по подготовке Конституции Уральской Республики, и 27 октября Свердловский областной Совет принял предложенный проект [7, л. 91]. В принятой Конституции было провозглашено, что «Уральская Республика обладает всеми правами, установленными Конституцией и законами Российской Федерации для республик в составе Российской Федерации, за исключением прав, которые Уральская Республика добровольно на себя не распространяет либо передает федеральным органам государственной власти в соответствии с настоящей Конституцией» (п. 2 ст. 15).

Конституция Уральской Республики не предполагала регионального суверенитета и распространяла на свою территорию государственный суверенитет Российской Федерации. Система государственной власти была разделена на законодательную, исполнительную и судебную ветви, представленные следующими органами: Законодательное собрание Уральской Республики (состоящее из двух палат - Республиканская дума и Палата представителей), губернатор Уральской Республики, правительство Уральской Республики, суды Уральской Республики [10, л. 18].

В октябре 1993 г. свердловские власти неоднократно обращались в Администрацию Президента с просьбой оказать содействие процессу преобразования области в республику [19, л. 68]. Однако сперва помощник Президента Ю.М. Батурин выразил сомнение в том, что образование Уральской Республики укрепит Россию, отметив, что в условиях коренного реформирования системы власти резкие изменения «в территориальном устройстве могут сделать процесс реформирования неуправляемым, неконтролируемым» [14, л. 72-73]. Также руководитель Администрации Президента С.А. Филатов, возглавлявший рабочую группу Конституционного совещания по доработке проекта Конституции, в ответ на обращение руководства Свердловской области о включении Уральской Республики в список республик отметил, что подобная просьба не может быть поддержана, поскольку ни Конституционное совещание, ни сам Президент таким правом не обладают, а также нет механизма изменения статуса субъекта [16, л. 92]. Филатов посоветовал «набраться терпения до принятия новой Конституции и федерального конституционного закона, регулирующего изменение конституционно-правового статуса субъекта РФ».

С критикой действий свердловских властей выступил и начальник Управления по работе с территориями Администрации Президента РФ Н.П. Медведев, отметив, что с правовой точки зрения решение областного Совета несостоятельно, поскольку Совет не обладает полномочиями на подобные действия, и такие решения не были возможны ни в рамках действующей на тот момент Конституции, ни в рамках новой. Примечательно, что в качестве рамок, в которых могут действовать субъекты Федерации, Медведев выделил исключительно последние указы Президента (№ 1400 и последующие) [13].

Спустя несколько дней были подписаны указы Президента, в соответствии с которыми решения Свердловского областного Совета народных депутатов были признаны не имеющими юридической силы с момента их принятия, а деятельность Совета и полномочия народных депутатов этого Совета прекращены [30]. Глава администрации Свердловской области Э.Э. Россель был освобожден от должности [31].

Напоследок Э.Э. Россель отметил, что свердловскими властями был предложен но- 
вый подход к территориальному устройству Российской Федерации, посредством которого возможно было бы уравнять «экономические и политические права регионов и людей, их населяющих». По его мнению, «крепкую единую, могучую, многонациональную Россию можно возродить, следуя лишь этим путем». Им было отмечено, что «успешное реформирование экономики возможно за счет максимального предоставления инициативы на местах, раскрепощения человека, создания настоящих творческих условий. Все это бы и означало перенос тяжести и ответственности за ход преобразований из центра в регионы» [29].

Результаты. Подводя итог, отметим следующее. Уральская Республика появилась в определенный период российской истории, когда в тяжелых экономических условиях и политической борьбе формировались основы будущей российской государственности. В феномене Уральской Республики пересеклось многое - угроза сепаратизма и распада единого государства, идея отказа от национального аспекта в государственно-территориальном устройстве, преодоление асимметрии субъектов Федерации, получение регионом большей самостоятельности. Примечательна в этом историческом явлении региональная инициатива, попытка из региона оказать существенное влияние на формирование общероссийской модели федеративного устройства. Эта попытка была решительным образом пресечена, более того, на протяжении всего процесса формирования Уральской Республики «в глубине» Администрации Президента эти действия рассматривались исключительно как угроза.

Как представляется, появление Уральской Республики оказало влияние на позицию национальных республик и сыграло свою роль в тех изменениях конституционного проекта, которые были сделаны на заключительной стадии его разработки. Ликвидация Уральской Республики пресекла потенциально большую государственную трансформацию, заключавшуюся в появлении самостоятельных регионов, становлении новой региональной политики и самой возможности выдвижения инициатив по формированию государственных основ «снизу».

Идея о создании Уральской Республики была устранена из российской политики, но отголоски процессов начала 90-х гг. ХХ в. остались в системе региональной власти Свердловской области и памяти населения сегодня. Федерализм после 1993 г. претерпел множество изменений, и потенциал развития федеративных отношений на сегодняшний день не исчерпан. Такие вопросы, как образование крупных регионов, расширение самостоятельности субъектов, пересмотр принципов государственно-территориального устройства, периодически актуализируются в политической повестке. Идея Уральской Республики, включавшая в себя некоторые ответы на проявившиеся в кризисный период вызовы Российского государства, может оказаться в том или ином виде востребованной в будущем.

\section{ПРИМЕЧАНИЕ}

${ }^{1}$ Исследование выполнено при финансовой поддержке РФФИ в рамках научного проекта № 19-39-90042 «Феномен Уральской Республики в становлении федеративной модели России в постсоветский период».

The reported study was funded by RFBR, project number 19-39-90042 "The phenomenon of the Ural Republic of 1993 in the Russian federal model formation in the post-Soviet period".

\section{СПИСОК ЛИТЕРАТУРЫ}

1. Аналитическая записка главного специалиста Тюнякина А.Д. «О территориальной основе государственного строительства» 1993 г. // Государственный архив Свердловской области (ГАСО).Ф. 2809-Р. - Оп. 1. - Д. 88. - Л. 1-12.

2. Аналитическая записка «Об изменении государственно-территориального статуса субъектов Федерации России» // Государственный архив Российской Федерации (ГА РФ). - Ф. 10115. - Оп. 1. Д. 974. -11 л.

3. Аналитическая справка «Административногосударственное устройство России: Центр и регионы», подготовленная Центром оперативной информации // ГА РФ. - Ф. 10115. - Оп. 1. - Д. 664. - 38 л.

4. Аналитическая справка «Федерализм и российская государственность» // ГА РФ. - Ф. 10115. Оп. 1. - Д. 472. -12 л.

5. Выбор сделан, господа! // Уральский рабочий. $-1993 .-29$ апр. - С. 1.

6. Декларация об изменении статуса Свердловской области от 01.07.1993 г. // Архив Президентского центра Б.Н. Ельцина. -Ф. 7.-Оп. 1.-Д. 187. -Л. 84-85. 
7. Декларация Свердловского областного Совета народных депутатов о принятии Конституции Уральской Республики от 27.10.1993 г. // Архив Президентского центра Б.Н. Ельцина. - Ф. 7. - Оп. 1. Д. 187.- Л. 91.

8. Кириллов, А. Д. Урал: от Ельцина до Ельцина (хроника политического развития, 1990-1997 гг.) / А. Д. Кириллов. - Екатеринбург : Изд-во Урал. ун-та, 1997. $-392 \mathrm{c}$.

9. Комлева, Н. А. Идея Уральской республики как выражение форалистического характера Российской Федерации / Н. А. Комлева - Электрон. текстовые дан. - Режим доступа: http://elar.urfu.ru/ bitstream/10995/41956/1/feodalizm_2001_03.pdf(дата обращения: 13.06.2020) - Загл. с экрана.

10. Конституция Уральской Республики // ГАСО. - Ф. 2809-Р. - Оп. 1. - Д. 92. - 94 л.

11. Леонтьев, Д. Причины провозглашения Уральской Республики / Д. Леонтьев. - М. : РИЦ ИСПИ РАН, 2001. - 32 c.

12. Мошкин, С. В. Уральская республика. Хроники / С. В. Мошкин // Дискурс-ПИ. - 2013. - Т. 10, № 3. - C. 103-107.

13. Опасные игры «во власть» // Российская газета. - 1993. - 6 нояб. - С. 2.

14. Письмо о пояснительной записке «Об образовании Уральской республики в составе Российской Федерации» // Архив Президентского центра Б.Н. Ельцина. - Ф. 7. - Оп. 1. - Д. 187. - Л. 72-73.

15. Письмо от 09.09.1993 г. № 7.4-697 // ГА РФ. Ф. 10026. - Оп. 1. - Д. 2786. - 5 л.

16. Письмо от 27.10.1993 г. № А4-271к // Архив Президентского центра Б.Н. Ельцина. - Ф. 7. Оп. 1. - Д. 187. - Л. 92.

17. План мероприятий по выполнению решения X сессии областного Совета народных депутатов «О статусе Свердловской области в составе РФ» : Прил. к постановлению Главы администрации Свердловской области и председателя Свердловского областного Совета народных депутатов от 20.07.1993 г. № 202/202 // Архив Президентского центра Б.Н. Ельцина. - Ф. 7. - Оп. 1. - Д. 187. Л. 93-97.

18. Пленарное заседание Конституционного совещания. - Электрон. дан. - Режим доступа: https://yeltsin.ru/archive/audio/64391/ (дата обращения: 15.06.2020). - Загл. с экрана.

19. Пояснительная записка «Об образовании Уральской республики в составе Российской Федерации» // Архив Президентского центра Б.Н. Ельцина. - Ф. 7. - Оп. 1. - Д. 187. - Л. 69-71.

20. Предварительное заключение отдела федеративных и межнациональных отношений // ГА РФ. Ф. 10026. -Оп. 1.-Д. 1915. - 9 л.

21. Предложения Малого Совета // Областная газета. $-1993 .-8$ июня. - С. 2.
22. Путь к устойчивой федерации // Областная газета. - 1993. - 25 авг. - С. 2.

23. Равноправия хотите? // Областная газета. 1993. -20 aпр. - С. 1.

24. Решение малого Совета Свердловского областного Совета народных депутатов от 15.04.1993 № 76/17 «О проведении опроса жителей Свердловской области 25 апреля 1993 г.» (с изм., внесенными 22.04.93) // Архив Президентского центра Б.Н. Ельцина. - Ф. 7. - Оп. 1. - Д. 187. - Л. 77.

25. Решение Свердловского областного Совета народных депутатов «О статусе Свердловской области в составе Российской Федерации» от 01.07.1993 г. // Архив Президентского центра Б.Н. Ельцина. - Ф. 7. - Оп. 1. - Д. 187. - Л. 83.

26. Рябов, А. С. Уральская Республика: мифы и реалии / А. С. Рябов // Свободная мысль. - 2007. № 6. - С. 149-159.

27. Средний Урал. Новый федерализм и региональная политика. - Екатеринбург : Доверие, 1993. $-94 \mathrm{c}$.

28. Тарасова, Е. А. Проблема федеративного устройства в проектах новой Конституции России в начале 1990-х годов / Е. А. Тарасова // Вестник СПбГУ. Сер. 2. - 2014. - Вып. 1. - С. 47-59.

29. Удар, еще удар! // Уральский рабочий. 1993. - 12 нояб. - С. 1.

30. Указ Президента Российской Федерации от 09.11.1993 г. № 1874. - Электрон. текстовые дан. Режим доступа: http://www.kremlin.ru/acts/bank/4784 (дата обращения: 13.06.2020). - Загл. с экрана.

31. Указ Президента Российской Федерации от 10.11.1993 г. № 1890. - Электрон. текстовые дан. Режим доступа: http://www.kremlin.ru/acts/bank/4797 (дата обращения: 13.06.2020). - Загл. с экрана.

32. Шаг к самостоятельности. Стоит ли драматизировать провозглашение Уральской республики? // Вечерний Екатеринбург. - 1993. - 20 июля. - С. 2.

33. Herrera, Yoshiko M. Imagined Economies: The Sources of Russian Regionalism / Yoshiko M. Herrera. - Cambridge : Cambridge univ. press, 2005. $318 \mathrm{p}$.

\section{REFERENCES}

1. Analiticheskaia zapiska glavnogo spetsialista Tiuniakina A.D. «O territorialnoi osnove gosudarstvennogo stroitelstva» 1993 g. [Analytical Note of the Chief Specialist A.D. Tyunyakin "On the Territorial Basis of State Building" 1993]. Gosudarstvennyi arkhiv Sverdlovskoi oblasti [State Archive of the Sverdlovsk Region], f. 2809-r, op. 1, d. 88, 1. 1-12.

2. Analiticheskaia zapiska «Ob izmenenii gosudarstvenno-territorialnogo statusa subieektov 
Federatsii Rossii» [Analytical Note "On Changing the State Territorial Status of the Subjects of the Federation of Russia"]. Gosudarstvennyi arkhiv Rossiiskoi Federatsii (GA RF) [The State Archive of the Russian Federation (GA RF)], f. 10115, op. 1, d. 974. 111.

3. Analiticheskaia spravka «Administrativnogosudarstvennoe ustroistvo Rossii: Tsentr i regiony», podgotovlennaia Tsentrom operativnoi informatsii [Analytical Report "Administrative and State Structure of Russia: Center and Regions", Prepared by the Center for Operational Information]. Gosudarstvennyi arkhiv Rossiiskoi Federatsii (GA RF) [The State Archive of the Russian Federation (GA RF)], f. 10115, op. 1, d. 664. 381.

4. Analiticheskaia spravka «Federalizm i rossiiskaia gosudarstvennost» [Analytical Report "Federalism and Russian Statehood"]. Gosudarstvennyi arkhiv Rossiiskoi Federatsii (GA RF) [The State Archive of the Russian Federation (GA RF)], f. 10115, op. 1, d. 472. 121.

5. Vybor sdelan, gospoda! [The Choice is Made, Gentlemen!]. Uralskii rabochii, 1993, April 29, p. 1.

6. Deklaratsiia ob izmenenii statusa Sverdlovskoi oblasti ot 01.07.1993 [Declaration on the Change in the Status of the Sverdlovsk Region of 01.07.1993]. Arkhiv Prezidentskogo tsentra B.N. Eltsina [Boris Yeltsin Presidential Archive], f. 7, op. 1, d. 187, 1. 84-85.

7. Deklaratsiia Sverdlovskogo oblastnogo Soveta narodnykh deputatov o priniatii Konstitutsii Uralskoi Respubliki ot 27.10.1993 g. [Declaration of the Sverdlovsk Regional Council of People's Deputies on the Adoption of the Ural Republic Constitution of 27.10.1993]. Arkhiv Prezidentskogo tsentra B.N. Eltsina [Boris Yeltsin Presidential Archive], f. 7, op. 1, d. 187, 1.91.

8. Kirillov A.D. Ural: ot El'tsina do El'tsina (khronika politicheskogo razvitiya, 1990-1997 gg.) [Ural: From Yeltsin to Yeltsin (The Chronicle of Political Development, 1990-1997)]. Ekaterinburg, Izd-vo Uralskogo Universiteta, 1997. 392 p.

9. Komleva N.A. Ideia Uralskoi respubliki kak vyrazhenie foralisticheskogo kharaktera Rossiiskoi Federatsii [The Idea of the Ural Republic as an Expression of the Formalistic Nature of the Russian Federation]. URL: http://elar.urfu.ru/bitstream/1 0995/41956/1/ feodalizm_2001_03.pdf(accessed 13 June 2020).

10. Konstitutsiia Uralskoi Respubliki [The Constitution of the Ural Republic]. Gosudarstvennyi arkhiv Sverdlovskoi oblasti [State Archive of the Sverdlovsk Region], f. 2809-r, op. 1, d. 92.941.

11. Leontev D. Prichiny provozglasheniia Uralskoi Respubliki [Reasons for the Proclamation of the Ural Republic]. Moscow, RITS ISPI RAN, 2001. 32p.

12. Moshkin S.V. Uralskaia respublika. Khroniki [Ural Republic. Chronicle]. Diskurs-PI [Discourse-P], 2013, vol. 10, no. 3, pp. 103-107.

13. Opasnye igry «vo vlast» [Dangerous Power Games]. Rossiiskaia gazeta, 1993, November 6, p. 2.
14. Pismo o poiasnitelnoi zapiske «Ob obrazovanii Uralskoi respubliki v sostave Rossiiskoi Federatsii» [Letter on the Explanatory Note "On the Formation of the Ural Republic Within the Russian Federation"]. Arkhiv Prezidentskogo tsentra B.N. Eltsina [Boris Yeltsin Presidential Archive], f. 7, op. 1, d. 187, 1. $72-73$.

15. Pismo ot 09.09.1993 g. no. 7.4-697 [Letter of 09.09.1993 no. 7.4-697]. Gosudarstvennyi arkhiv Rossiiskoi Federatsii (GA RF) [The State Archive of the Russian Federation (GA RF)], f. 10026, op. 1, d. 2786.51 .

16. Pismo ot 27.10.1993 g. no. A4-271k [Letter of 27.10.1993 no. A4-271k]. Arkhiv Prezidentskogo tsentra B.N. Eltsina [Boris Yeltsin Presidential Archive], f. 7, op. 1, d. 187, 1. 92.

17. Plan meropriiatii po vypolneniiu resheniia $\mathrm{X}$ sessii oblastnogo Soveta narodnykh deputatov «O statuse Sverdlovskoi oblasti v sostave RF»: Pril. k postanovleniyu Glavy administratsii Sverdlovskoy oblasti i predsedatelya Sverdlovskogo oblastnogo Soveta narodnykh deputatov ot 20.07.1993 g. № 202/202 [Plan of Measures to Implement the Decision of the $10^{\text {th }}$ Session of the Regional Council of People's Deputies "On the Status of the Sverdlovsk Region in the Russian Federation": Regulation Supplement to the Order of the ChiefExecutive of the Sverdlovsk Region Administration and the Chairman of the Sverdlovsk Regional Council of People's Deputies of 20.07.1993 № 202/202]. Arkhiv Prezidentskogo tsentra B.N. Eltsina [Boris Yeltsin Presidential Archive], f. 7, op. 1, d. 187, 1.93-97.

18. Plenarnoe zasedanie Konstitutsionnogo soveshchaniia [Plenary Session of the Constitutional Meeting]. URL: https://yeltsin.ru/archive/audio/64391/ (accessed 15 June 2020).

19. Poiasnitelnaia zapiska «Ob obrazovanii Uralskoi respubliki v sostave Rossiiskoi Federatsii» [Explanatory Note "On the Formation of the Ural Republic Within the Russian Federation"]. Arkhiv Prezidentskogo tsentra B.N. Eltsina [Boris Yeltsin Presidential Archive], f. 7, op. 1, d. 187, 1. 69-71.

20. Predvaritelnoe zakliuchenie otdela federativnykh i mezhnatsionalnykh otnoshenii [Preliminary Conclusion of the Department of Federal and Interethnic Relations]. Gosudarstvennyi arkhiv Rossiiskoi Federatsii (GA RF) [The State Archive of the Russian Federation (GA RF)], f. 10026, op. 1, d. 1915.91 .

21. Predlozheniia Malogo Soveta [Suggestions of the Small Council]. Oblastnaia gazeta, 1993, June 8, p. 2.

22. Put k ustoichivoi federatsii [The Road to Sustainable Federation]. Oblastnaia gazeta, 1993, August 25, p. 2.

23. Ravnopraviia khotite? [Do You Want Equality?]. Oblastnaia gazeta, 1993, April 20, p. 1.

24. Reshenie malogo Soveta Sverdlovskogo oblastnogo Soveta narodnykh deputatov ot 15.04.1993 
no. $76 / 17$ «O provedenii oprosa zhitelei Sverdlovskoi oblasti 25 aprelia 1993 g.» (s izm., vnesennymi 22.04.93). [Decision of the Small Council of the Sverdlovsk Regional Council of People's Deputies of April 15, 1993 no. 76/17 "On Conducting a Survey of Residents of the Sverdlovsk Region on April 25, 1993" (As Amended on 22.04.93)]. Arkhiv Prezidentskogo tsentra B.N. Eltsina [Boris Yeltsin Presidential Archive], f. 7, op. 1, d. 187, 1. 77.

25. Reshenie Sverdlovskogo oblastnogo Soveta narodnykh deputatov «O statuse Sverdlovskoi oblasti v sostave Rossiiskoi Federatsii» ot 01.07.1993 g. [The decision of the Sverdlovsk Regional Council of People's Deputies “On the status of the Sverdlovsk Region Within the Russian Federation" of 01.07.1993] Arkhiv Prezidentskogo tsentra B.N. Eltsina [Boris Yeltsin Presidential Archive], f. 7, op. 1, d. 187, 1. 83.

26. Riabov A.S. Uralskaia Respublika: mify i realii [Ural Republic: Myths and Realities]. Svobodnaia mysl, 2007, no. 6, pp. 149-159.

27. Srednij Ural. Novyj federalizm i regional naja politika [Middle Urals. New Federalism and Regional Policy]. Ekaterinburg, Doverie Publ., 1993. 94 p.

28. Tarasova E.A. Problema federativnogo ustroistva v proektakh novoi Konstitutsii Rossii v nachale 1990-kh godov [Problem of the Federal Organization in Drafts of the New Constitution of Russia in the Beginning of the 1990s]. Vestnik SPbGU [Vestnik of Saint Petersburg University. Ser. 2], 2014, iss. 1, pp. 47-59.

29. Udar, eshche udar! [Blow, Another Blow!]. Uralskii rabochii, 1993, November 12, p. 1.

30. Ukaz Prezidenta Rossiiskoi Federatsii ot 09.11.1993 g. no. 1874 [Decree of the President of the Russian Federation of 09.11.1993 no. 1874]. URL: http://www.kremlin.ru/acts/bank/4784 (accessed 13 June 2020).

31. Ukaz Prezidenta Rossiiskoi Federatsii ot 10.11.1993 g. no. 1890 [Decree of the President of the Russian Federation of 10.11.1993 no. 1890]. URL: http://www.kremlin.ru/acts/bank/4797 (accessed 13 June 2020).

32. Shag k samostoiatelnosti. Stoit li dramatizirovat provozglashenie Uralskoi respubliki? [A Step Towards Independence. Is it Worth Dramatizing the Proclamation of the Ural Republic?]. Vechernii Ekaterinburg, 1993, July 20, p. 2.

33. Herrera, Yoshiko M. Imagined Economies: The Sources of Russian Regionalism. Cambridge, Cambridge univ. press, 2005. 318 p.

\section{Information About the Author}

Igor V. Osipov, Trainee Researcher, Interethnic and Interfaith Relations Management Department, Moscow State University, Leninskie Gory, 1, 119234 Moscow, Russian Federation, igorosipov2020@gmail.com, https://orcid.org/0000-0001-7697-1629

\section{Информация об авторе}

Игорь Вячеславович Осипов, стажер-исследователь кафедры управления в сфере межэтнических и межконфессиональных отношений, Московский государственный университет им. М.В. Ломоносова, Ленинские горы, 1, 119234 г. Москва, Российская Федерация, igorosipov2020@gmail.com, https://orcid.org/0000-0001-7697-1629 